\title{
Association of Entrepreneurial Behaviour with Personal and Socio-Economic Characteristics of Rural Women
}

\author{
Sonu Mertiya ${ }^{1}$, Rajshree Upadhyay ${ }^{2}$ \\ College of Home Science, MPUAT, Udaipur (Raj.)
}

\begin{abstract}
The present paper aims at highlighting the association of entrepreneurial behaviour with personal and socio-economic characteristics of rural women. The study was conducted in Udaipur district of Rajasthan with a total sample of 100 rural women. The major findings reveal that Socio personal variables like age, occupation, education, land holding, family type, family size, livestock ownership, media ownership, extension contact, socio-economic status were found to be associated with the entrepreneurial behaviour of the rural women.
\end{abstract}

Keywords: Entrepreneurial behaviour, rural women, associated factors.

\section{Introduction}

Women in India play a major role in shaping country's economy through their active participation in various income generating activities. The position and status of women in any society is an index of its civilization. The prosperity and growth of a nation depends on the status and development of its women as they not only constitute nearly half of the population, but also positively influence the growth of remaining half of the population. Women entrepreneurship has been recognized as an important source of economic growth. By establishing their new venture women entrepreneurs generate new jobs for themselves and others and also provide society with different solutions to management, organization and business problems. Women entrepreneurs often face gender-based barriers to starting and growing their businesses, like discriminatory property, matrimonial and inheritance laws and cultural practices; lack of access to formal finance mechanisms limited mobility and access to information and networks, etc.Thus, the present paper aims at highlighting the Association of Entrepreneurial Behaviour with Personal and SocioEconomic Characteristics of Rural Women.

\section{Methodology}

The study conducted in Mavli and Girwa randomly selected of Udaipur District, Rajasthan. From the list, 50 rural women from panchayat samiti were selected randomly to form a total sample of 100 respondents.Data were collected with the help of personal interview schedule. Frequency,percentage, and chi square test were used for analysis of the data statistically.

\section{Results and Discussion}

An attempt was made to study the association of personal and socio economic characteristics of rural women with their entrepreneurial behaviour in order to see whether their entrepreneurial behaviour is affected by these characteristics or not. The association of the characteristics was worked out with two categories of entrepreneurial behaviour i.e. low and medium as there were no respondents in high category. Expected frequencies in different categories of personal and socio- economic characteristics were found to be less, so the categories were pooled for applying chi square test.

i) Age: One the basis of their age, the respondents was categorized in two i.e. below 45 years and above 45 years. As seen from Table (1) chi square value was worked out to be 1.068 , which is non-significant, indicating no association of age with entrepreneurial behaviour. The findings are in consonance with Jha (2012) who reported non-significant association between age and entrepreneurial behaviour.

ii) Occupation: The respondents were categorized into two categories of wage earners and non-wage earners. Table (1) reveals that chi square value is 1.795 , showing no association between occupation and entrepreneurial behaviour. This may be due to the reason that the half of the respondents had farming as their occupation and rest of the respondents were in service sector of the occupation. The findings are in line with Ravi (2007) who reported that occupation is not associated with entrepreneurial behaviour of the respondents.

iii) Education: The association between entrepreneurial behaviour and education categories of literate and illiterate showed significant chi square value (2.181). It can be inferred that education is an important factor determining the entrepreneurial behaviour of an individual as cited by Patel et al. (2003), Tamilselvi and Sudhakar (2007) and Jaiswal and Patel (2012). The respondents who were educated were more innovative and had higher self-confidence, planning and coordinating abilities and better in taking decisions compared to the uneducated respondents who were seen apathetic, status quo-maintaining and feel happy in existing conditions. The results are in consonance with Shyamlie and Saini (2011) who opined that education guides the thinking process of the individual and improves the entrepreneurial behaviour.

iv) Land holding: The respondents of the study fell into two categories of either landless or having land above 10 acres. 


\section{International Journal of Science and Research (IJSR) \\ ISSN (Online): 2319-7064 \\ Index Copernicus Value (2015): 78.96 | Impact Factor (2015): 6.391}

It is evident from Table (1) that there was significant association between entrepreneurial behaviour and land holding of the respondents. Pandeti (2005), Chaudhari (2006) reported alike that land holding was significantly associated with entrepreneurial behaviour.

v) Family type: The association between types of family was seen with their entrepreneurial behaviour which was found to be non-significant with chi square value 0.313 . Chaudhari (2006) reported alike for family type and entrepreneurial behaviour association.

Table 1: Association of Entrepreneurial Behaviour with Personal and Socio-economic variable

\begin{tabular}{|r|c|c|}
\hline S. No. & Personal variables & Chi square Value \\
\hline 1. & Age & $1.068 \mathrm{NS}$ \\
\hline 2. & Occupation & $1.795 \mathrm{NS}$ \\
\hline 3. & Education & $2.181^{*}$ \\
\hline 4. & Land holding & $6.825^{* *}$ \\
\hline 5. & Family type & $0.313 \mathrm{NS}$ \\
\hline 6. & Family size & $0.384 \mathrm{NS}$ \\
\hline 7. & Livestock ownership & $17.600^{* *}$ \\
\hline 8. & Media ownership & $0.044 \mathrm{NS}$ \\
\hline 9. & Extension contact & $0.4703^{* *}$ \\
\hline 10 & Socio-economic status & $2.105 \mathrm{NS}$ \\
\hline
\end{tabular}

** Significant at 0.01 level of significance;

*Significant at 0.05 level of significance;

NS- Non significant.

vi) Family size: The respondents were categorized into two groups i.e. having family size up to 5 members and above 5 members. The data in Table (1) reveal that the association between entrepreneurial behaviour \& family size was not found to be statistically significant. Anitha (2004) reported alike that family size of farm women did not have any significant relationship with their entrepreneurial behaviour.

vii) Livestock ownership: The association of small, medium and large herd size possessed by the respondents with their entrepreneurial behaviour came out to be highly significant with chi square value 17.60. The respondents, who possessed more number of dairy animals were getting more milk yield and higher income by selling milk.

viii) Media ownership: The association of entrepreneurial behaviour of media ownership with chi square value 0.044

ix) Extension contact:The association of entrepreneurial behaviour of media ownership with chi square value 0.4703 .

x) Socio economic status: On the basis of socio economic status, the respondents were categorized into two groups i.e. those having SES score below 35 and above 35 (Total score being 71). Data in Table (1) show non-significant association between the two.

\section{Conclusion}

The socio personal variables like education, land holding, livestock ownership were found to be associated with the entrepreneurial behaviour of the rural women.

\section{Future Scope}

Comparative studies can be conducted among tribal, rural and urban women.

\section{References}

[1] Chaudhari, R.R. 2006. A Study on Entrepreneurial Behavior of Dairy Farmers.Ph.D.Thesis submitted to University of Agricultural Sciences, Dharwad, Karnataka.

[2] Jaiswal, A. and Patel, M.M. 2012. Entrepreneurial behaviour of Rural Women.Indian Journal of Extension Education.12 (1): 55-59.

[3] Pandeti, C. 2005. A Study on Entrepreneurial Behaviour of Farmers in Rainchur District of Karnataka. M. Sc. (Agri.) Thesis submitted to University of Agricultural Sciences, Dharwad.

[4] Rodge, J. and Borkar, S., 2011. Development of the scale to measure entrepreneurial behaviour of women entrepreneur.Asian Journal of Home Science.6(2): 214215

[5] Citedfromhttp://www.cabdirect.org/abstracts/201332876 64.html;jsessionid $=8674$ D300E9969025295ADDBC27D $8 F A D 2$ retrieved on March $3^{\text {rd }}, 2016$.

[6] Sharma, Indu 2005. A critical analysis of entrepreneurial behaviour of rural women in Buland Shahr district of Uttar Pradesh. Unpublished Ph.D Thesis, Department of Agricultural Extension, A.S. (P.G) College, LakhotiBulandShahr, Uttar Pradesh.

\section{Author Profile}

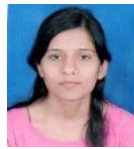

Sonu Mertiya is Master of Science (Home Science), Dept. of HECM, College of Home Science, MPUAT, Udaipur (Raj.)

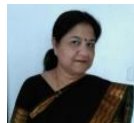

Rajshree Upadhyay (second author), Professor and Head, Dept. of HECM, College of Home Science, MPUAT, Udaipur (Raj.) 